\title{
What Shapes Companies' Corporate Sustainability? Belgian Pharma Businesses' Views On Global Sustainable Development
}

\author{
François Van Leeuw (E-mail: fvleeuw@vub.ac.be), Vrije Universiteit Brussel \\ Ilse Scheerlinck (E-mail: ilse.scheerlinck@vub.ac.be), Vesalius College, Vrije Universiteit Brussel ${ }^{1}$
}

\begin{abstract}
'Globalisation' and 'sustainable development' are nowadays the buzzwords in socio-economic discussions. However, research on corporate sustainability in an international business context has only recently got off the ground and is still underdeveloped. In this paper, we examine the determinants of Belgium-based pharmaceutical companies' views on sustainable development. Particular emphasis is on long run environmental and social sustainability issues. Observations on pharma companies' views are gathered through a survey of the industry. We empirically test companies' positions using principal components and ordinary least squares. We find that firms' positions on sustainable development are determined by internal and external company-specific characteristics. Results also show that government regulation is a significant driver of companies' awareness of sustainability issues.
\end{abstract}

\section{Introduction}

During the last fifteen to twenty years alternate views on how to do (international) business have received growing attention. Doing business in a more sustainable way is one of those views. Being driven by various stakeholders, business leaders realize it may be profitable to integrate environmental and social aspects into the company's decision-making process. Especially pharmaceutical companies, operating and competing on a global level, find themselves increasingly challenged on the environmental and social dimension of their business.

Business operations may have effects on bystanders. A company's decision to pollute leads to negative externalities that may be reduced through either government regulation or self-regulation by the company. From a social perspective, on the other hand, a company's operations may affect society's wealth and income distribution. Reconciling corporate interests with interests of a wider society may be achieved through strong engagement with stakeholders, both primary (including shareholders, employees, consumers) and secondary (including NGOs, suppliers, local communities, media). Growing internationalization and globalization of the economy have increased their role and has brought the issue of sustainable development high on the agenda.

Existing research in the field of corporate sustainability is still fragmentary, with a preponderance of empiricism over theory. Dyllick and Hockerts (2002) rightly state that more attention need to be given to theory building of corporate sustainability. A narrowly related area is the issue of 'corporate social performance', an area that studies the factors determining companies' corporate responsiveness and responsibilities towards the 'peopleplanet-profit' triad.

The purpose of this paper is to examine what determines Belgium-based pharmaceutical companies' views on sustainable development, particularly the environmental and the social angle. We hypothesize that pharma businesses" views are shaped by: (1) internal factors relating to company-specific characteristics, and (2) external

\footnotetext{
${ }^{1}$ We are very grateful to Herbert Glejser for his valuable comments.
} 
factors including both the international context and government regulations faced by companies when doing business. Though emphasis is mainly on the empirical aspect, we aim at stimulating the debate on both theory and empiricism in a field where still much remains to be explored.

The pharmaceutical industry is a major case for different reasons. Operating in a highly internationalized industry, pharmaceutical companies have a growing interest in the further course of globalization and the related issue of sustainability. The industry's international activity covering both the industrialized and the less developed world (e.g., debate on the protection of intellectual property rights and price setting) explain the relevance as major research subject.

Recently, Deloitte Touche Tohmatsu (2002) ${ }^{2}$ evaluated global pharmaceutical companies' reporting on 'sustainability', covering environment, health and safety issues. The survey shows that reporting quality and the degree of maturity varies significantly between companies. From the survey it also appears that criteria related to social impacts receive rather low scores. Our study attempts to fill the gap by studying pharma businesses' views on both environmental and social sustainability, and examining what leads them to think what they think.

The paper is organized as follows. Section II describes the sustainability issues, sample and questionnaire. Section III analyzes the various determinants of firms' positions on sustainable development. Section IV discusses statistical model and results. Finally, section V centres on the main conclusions.

\section{Sustainability Issues, Sample And Questionnaire}

The data for this study were collected from two sources. The first is a questionnaire sent to the general managers of the 124 pharmaceutical companies operating in Belgium and affiliated to the professional organisation 'Belgian Pharmaceutical Industry Association'. The second source of information are the annual reports of all participating companies. The pharmaceutical companies were asked to position themselves on the following issues:

Environmental issue, including questions on:

- $\quad$ the obligation of an environmental plan;

- the obligation to make this environmental plan public to their primary and/or secondary stakeholders;

- $\quad$ the use of environment-friendly packaging in production and purchasing process;

- $\quad$ the influence of environmental criteria on investment decisions;

- $\quad$ the impact of production on ecology;

- the acceptance of the ISO 14000 norms $^{3}$.

- the importance of primary and/or secondary stakeholders.

Social issue, including questions on:

- $\quad$ the acceptance of the ILO (International Labour Organisation) norms;

- $\quad$ investment decisions in relation to social protection;

- $\quad$ opportunities for permanent education;

- $\quad$ the importance of staff appraisal;

- $\quad$ the possibility of doing homework;

- $\quad$ the importance of day nursery;

- $\quad$ the balance between family and work;

- the company's social role;

- the importance of primary and/or secondary stakeholders.

2 http://www.deloitte.com/dtt/cda/doc/content/PharmabriefFINAL(1).pdf

3 The ISO 14000 series provides a framework for good environmental management and were developed to provide a practical toolbox to assist in the implementation of actions supportive to sustainable development (http://www.iso.ch/iso/en/aboutiso/introduction/achievements.html). 
50 questionnaires were returned, of which 9 were incomplete on the environmental issue, leaving 41 usable questionnaires (or 33 percent of the population). Of the 50 questionnaires 14 were incomplete on the social issue, leaving 36 usable questionnaires (or 29 percent of the population).

\section{Determinants Of Firms' Positions On Environmental And Social Sustainability}

We hypothesize that the following characteristics of pharmaceutical companies determine their position on environmental sustainability: research and development, patents activity, experienced competition from inside and outside the European Union, foreign activity, net return on shareholder funds before taxes, importance of ISO 14000 norms, government as controller and regulator, and importance of stakeholders.

The following characteristics are hypothesized to influence a company's position on social sustainability: research and development, patents activity, experienced international competition, foreign activity, net return on shareholder funds before taxes, government as provider of social security and as regulator, importance of training programs followed by men and women, the importance of homework done by employees, and importance of stakeholders.

\subsection{Competition From Other Pharmaceutical Companies}

Over the last two decades growing globalization of the world economy has increased international competition. We therefore expect that the pressure from international competition is a major influence on a company's position on sustainability. Companies facing fierce competition from other companies may be either in favour or against the environmental and social angle of sustainable development. The case for being 'in favour' (i.e., a positive relationship) is that companies may consider competition as an incentive to improve their performance, especially through corporate sustainability. The case for being 'against' (i.e. a negative relationship) is that competition leads companies to follow a rather defensive strategy, thus avoiding any form of corporate sustainability. Hence, whether the relationship is positive or negative is an empirical matter.

We expect that:

Hypothesis 1: Companies experiencing fierce competition will either favour or disapprove the environmental and social issue.

We distinguish between competition from other companies in the European Union, competition from companies outside the European Union and international competition in general (see statistical analysis for more details). Measuring competition directly is problematical. We solve this problem using a variable which reflects a firm's perception of EU-competition, non EU-competition and overall international competition. In the questionnaire each firm was asked how it assessed the foreign competitive threat on a seven-point scale ranging from 'extremely weak' to 'extremely strong'.

\subsection{Research and Development (R\&D)}

R\&D, particularly in the pharmaceutical industry, cannot be dissociated from sustainability. We may argue that research-based companies more easily achieve competitive advantages, and will therefore favour sustainability. In addition R\&D may be developed for the purpose of implementing ecological strategies (see e.g., Blum, Kusterer \& Hussai, 2001 for a discussion). Consequently, they will possess more knowledge and financial possibilities for implementing good social and environment-friendly policies that may lead to sustainable development. However companies may invest in $\mathrm{R} \& \mathrm{D}$ for the purpose of merely maximizing profits. This focus on profit maximization, often under the influence of a firm's shareholders, may be at the cost of stimulating sustainability. In that case, intense R\&D may lead pharmaceutical companies to disapprove social and environmental sustainability. Therefore,

Hypothesis 2: Companies investing intensively in $R \& D$ will be either more or less in favour of the environmental and social issue. 
Research and development is measured as the percentage turnover spent on R\&D.

An alternative way for measuring a company's research intensity is through its patent activity (measured by the proportion of patents value to turnover in 2001). However, both variables do not measure the same. While the percentage of $R \& D$ measures the amount of money invested by the company in research and development, the percentage of patents measures the share of products protected by patents.

We may argue that, unlike generic companies, patent-based companies reduce the accessibility of other markets such as less developed countries, thus discouraging sustainable development. Hence:

Hypothesis 3: Companies characterized by intense patent activity will be against the environmental and social issue.

\subsection{Foreign Activity}

A key determinant of a company's position on sustainable development is its degree of foreign activity. The pharmaceutical industry in particular is strongly characterized by international business. We hypothesize that highly international companies are in favour of environmental and social sustainability. These, mostly large, firms operate on a global scale which makes them more visible and thus more susceptible to public scrutiny by stakeholders such as the media and consumers. Hence the incentive for corporate sustainability.

In their study on multinational operations and stakeholder management Meznar and Johnson (1996) found that internationally oriented companies more easily comply with regulatory requirements and legislation in the host country where they are established.

Hypothesis 4: The more important a company's foreign activity, the more it will be in favour of the environmental and social issue.

A company's foreign activity is measured by the number of regions in which the company operates.

\subsection{Net Return On Shareholder Funds Before Taxes}

Are profitable firms in favour or against sustainability? The issue is debatable. Firms with a high level of financial performance will have more financial possibilities to implement sustainable environmental and social policies. On the other hand, high profits may reflect shareholder priority which may be at the cost of sustainability. We used the net return on shareholder funds before taxes as a measure for financial performance of the pharmaceutical firm. The net return on shareholder funds before taxes reports us how much return the shareholders received in 2001 for each 100 Euro invested in the company. A lot of research has been done concerning the influence of firms' financial position on corporate social performance. We found twenty eight studies with a positive relationship between corporate social performance and financial performance (Bragdon \& Marlin (1972); Bowman \& Haire (1975); Moskowitz (1975); Parket \& Eilbert (1975); Belkaoui (1976); Heinze (1976); Sturdivant \& Ginter (1977); Chugh, Haneman \& Mahapatra (1978); Bowman (1978); Ingram (1978); Spicer (1978); Anderson \& Frankle (1980); Fry, Keim \& Meiners (1982); Shane and Spicer (1983); Cochran \& Wood (1984); Rockness \& Schlachter (1986); Cowen, Ferreri \& Parker (1987); Spencer \& Taylor (1987); Wokutch \& Spencer (1987); McGuire, Sundgren \& Schneeweis (1988); Morris, Rehbein, Hosseini \& Armacost (1990); Cotrill (1990); Roberts (1992); Hart \& Ahuja (1994); Graves \& Waddock (1997); Preston and O'bannon (1997); Roman, Hayibor \& Agle (1999); Orlitzky (2001); Orkitzky \& Benjamin (2001), Simpson \& Kohers (2002)). Twelve other studies found a significant negative relationship between corporate social performance and financial performance (Vance (1975); Strachan, Smith \& Beedles (1983); Wier (1983); Eckbo (1983); Jarrell \& Peltzman (1985); Marcus\&Goodman (1986); Davidson, Chandy \& Cross (1987); Hoffer, Pruitt \& Reilly (1988); Davidson \& Worrell (1988); Bromiley \& Marcus (1989); Frooman (1997); Mc William \& Siegel (2000)). We only found eight studies indicating no significant relationship (Folger \& Nutt (1975); Alexander \& Bucholz (1978); Freedman \& Jaggi (1982); Chen \& Metcalf (1984); Aupperle, Carroll \& Hatfield (1985); Freedman \& Jaggi (1986); Patten (1990)). 
Given the argument that a high level of performance either increases or decreases the possibility to undertake corporate sustainability, we hypothesize that:

Hypothesis 5: Companies having high net return on shareholder funds before taxes will be either in favour or against the environmental and social issue.

Net return on shareholder funds is measured using data from the annual reports of the companies. The net return on shareholder funds before tax is calculated as follows:

(Profit for the year after taxes - loss for the year after taxes + income taxes) / shareholder funds

\subsection{The Role Of The Government}

Globalization of business has increased the role of the government. Though not all countries operate the same environmental and social standards, the European Union has attempted to create a level-playing-field which aims at harmonizing regulatory and legislative requirements for doing business. Particularly relevant to the pharmaceutical industry is the government's role of:

$\begin{array}{ll}- & \text { legislator } \\ \text { - } & \text { controller } \\ & \text { provider of social security }\end{array}$

The importance of government regulations is also explained by Porter (1991) and Porter and Van der Linde (1995) who state that when government implements strong environmental regulations, standards will move up, thus leading to competitive advantages. Therefore we expect that companies perceiving the government as an important legislative entity will be more in favour of sustainable development.

In their study over the 750 largest multinationals in Canada, Henriques and Sadorsky (1996) found that a higher regulation norm leads to faster implementation of the environmental plan.

In the social field the government also plays a role as provider of social security. This role characterizes the typical welfare-state, of which Belgium is an illustration. Therefore:

Hypothesis 6: The more important the government is as controller the more the company will favour the environmental and social issue.

Hypothesis 7: The more important the government is as legislator the more the company will favour the environmental and social issue.

Hypothesis 8: The more important the government is as provider of social security the more the company will favour the social issue.

Companies' perception of the government's role as controller, legislator and provider of social security is measured through the questionnaire by asking them to position themselves on a seven-point scale going from 'extremely unimportant' to 'extremely important'.

\subsection{Iso14000 Norms}

Globalization of business has led to a growing concern among politicians, the business society, stakeholders and other interest groups about the linkage between protection of the environment and safeguarding international competitiveness of multinational companies. The Iso 14000 norms offer companies a framework for good environmental strategy, which may improve their position in local and international markets. 
Whilst the iso14000 norms do not measure the amount of environmental protection that should be reached by companies, they rather offer the companies a framework that should be followed when applying good environmental strategy. Poduska et al. (1992) and Reilly (1992) found a positive relationship between environmental protection and corporate social performance. We expect that firms who consider the Iso14000 norms as important will have an incentive to stimulate corporate sustainability, especially the environmental issue.

Hypothesis 9: A firm implementing the Iso14000 norms will be more in favour of the environmental issue.

The variable is measured through the questionnaire by asking firms to position themselves on a seven-point scale, ranging from 'extremely disagree' to 'extremely agree'.

\subsection{Training}

An important aspect of job satisfaction is the way employees can learn through trainings offered by the company. The more a company offers training possibilities to employees, the more people's skills will be improved. We expect that the larger the number of trainings followed by employees, the more the pharmaceutical firms will favour sustainable development, especially the social issue. Therefore:

Hypothesis 10: The larger the number of trainings followed by men, the more the company will be in favour of the social issue.

Hypothesis 11: The larger the number of trainings followed by women, the more the company will be in favour of the social issue.

Data on this variable have been gathered from the company reports, and reflect the number of trainings followed per employee.

\subsection{Homework}

Increased job satisfaction and, hence, social sustainability may also result from other internal measures taken in the company. An example is the provision of homework. We expect that companies stimulating homework for their employees will be more in favour of social sustainability. Homework allows employees to work in a more flexible way and to find a better balance between professional and private life. Hence:

Hypothesis 12: The higher the number of employees doing homework, the more the company will be in favour of the social issue.

The variable is measured by the company's number of employees working at home now and then, data obtained through the questionnaire.

\subsection{The Role Of Stakeholders}

Stakeholder theory suggests that a business, when pursuing its objectives, is susceptible to a number of interest groups. Traditionally, the theory centred on a small number of groups being directly involved with the organisation: shareholders, clients and employees. However, the theory more and more focuses on groups representing a wider society, e.g., the media, communities and green NGOs (Patton, 2003). Henriques and Sadorsky (1996) found a positive and significant influence of customers, shareholders and the community on a company's implementation of an environmental plan.

In this paper we analyze the influence of five stakeholder groups: shareholders, employees, media, clients and green NGOs. 
We expect shareholders to have a negative influence on a firm's view on both environmental and social sustainability. The greater the importance given to shareholders the less eager the company will be to favour sustainability. Indeed, shareholders invest money in a company to make profits, which may be at the cost of a wider objective of corporate sustainability.

With regard to employees, we expect that companies perceiving employees as important, will be less in favour of environmental sustainability. Labour costs may indeed reduce financial possibilities available for environmental sustainability. On the other hand, we expect that companies perceiving employees as important will favour the social issue.

Clients, green NGOs and media are hypothesized to stimulate a company's view on sustainability. Being exposed to these stakeholders, who either favour sustainability or scrutinize companies on this issue, makes companies highly visible and thus vulnerable; hence the incentive. Therefore we expect that:

Hypothesis 13: The more priority is given to shareholders, the less the company will be in favour of the environmental and social issue.

Hypothesis 14: The more priority is given to employees, the less the company will be in favour of the environmental issue.

Hypothesis 15: The more priority is given to employees, the more the company will be in favour of the social issue.

Hypothesis 16: The more priority is given to clients, the more the company will be in favour of the environmental and social issue.

Hypothesis 17: The more priority is given to green NGOs, the more the company will be in favour of the environmental issue.

Hypothesis 18: The more priority is given to the media, the more the company will be in favour of the environmental and social issue.

The variables on stakeholder priority were measured through the questionnaire by asking companies to rank the five stakeholders in order of importance.

\section{Statistical Model And Results}

\subsection{Model}

As mentioned above, two issues of sustainable development are analyzed throughout this paper, the environmental issue and the social issue.

We used principal components to construct a single dependent variable (one for the environmental issue and one for the social issue) out of the answers to the various issues obtained through the questionnaire. Principal components creates a dependent variable that summarizes in our case the different answers related to the two sustainability issues. The factor loadings of the first principal component - the principal component that accounts for the largest proportion of the total variance - are used as a weight to create the dependent variable. The dependent variable takes a high value when a company favours (environmental or social) sustainability and a low value when the company is against.

The regression model of the environmental issue has the following equation: 
Environmental issue of sustainable development

$=\alpha_{0}+\alpha_{1}$ (percentage of patents)

$+\alpha_{2}$ (perception of competition from outside the European Union)

$+\alpha_{3}$ (perception of competition from inside the European Union)

$+\alpha_{4}$ (foreign activity)

$+\alpha_{5}$ (net return on shareholder funds before taxes)

$+\alpha_{6}$ (Iso14000 norms)

$+\alpha_{7}$ (government as controller)

$+\alpha_{8}$ (government as legislator)

$+\alpha_{9}$ (stakeholder variable)

$+\varepsilon$

In order to avoid a fall in the degrees of freedom, the five stakeholder variables (shareholders, employees, clients, green NGOs and media) variables are alternately included in the model. The same method is applied to the two R\&D variables (percentage of R\&D and percentage of patents).

The regression model of the social issue has the following equation:

Social issue of sustainable development

$=\alpha_{0}+\alpha_{1}$ (percentage research and development)

$+\alpha_{2}$ (perception of international competition)

$+\alpha_{3}$ (foreign activity)

$+\alpha_{4}$ (net return on shareholder funds before taxes)

$+\alpha_{5}$ (government as legislator)

$+\alpha_{6}$ (government as provider of social security)

$+\alpha_{7}$ (number of trainings followed by men)

$+\alpha_{8}$ (number of trainings followed by women)

$+\alpha_{9}$ (percentage of home workers)

$+\alpha_{10}$ (stakeholder variable)

$+\varepsilon$

Along similar lines, we alternately included only one stakeholder variable in the model for social sustainability (except for green NGOs, which are not expected to influence a company's view on social sustainability).

\subsection{Results}

The results are reported in Tables 1 and 2. Models 1 through 5 in Table 1 display the results for the environmental issue with each model alternately including another stakeholder variable. Models 6 to 10 are similar to the first five models, except for the percentage of R\&D which is replaced by the percentage of patents. The same method is applied to the social issue reported in Table 2.

The models performed well in terms of overall significance. The first principal component used for the creation of our dependent variable accounts for $44 \%$ of the variance of the environmental dependent variable and for $38 \%$ of the variance for the social issue.

In models 1 to 5 of Table 1 the F-value shows an overall significance at the $1 \%$ level. The five models show that strong competition from inside the EU leads pharmaceutical companies to favour environmental sustainability. However, competition from outside the EU is rather seen as a threat leading companies to oppose environmental sustainability. 
As far as the percentage R\&D is concerned, the coefficient takes the expected sign but does not have a significant influence on how pharmaceutical companies view environmental sustainability. As expected, patentintensive companies are less in favour of environmental sustainability. The results also indicate that companies that consider the ISO14000 framework as important are more in favour of environmental sustainability.

The variables on net return on shareholder funds before taxes, government as controller and legislator and the stakeholder variables do not appear to have any significant influence on a company's view on environmental sustainability.

Table 2 summarizes the results of the social issue. The F-tests indicate an overall significance at the $2.5 \%$ level for the first four models, and at the $20 \%$ level for the last four models. The results show that intensive R\&D, strong international competition ${ }^{4}$ and training by men lead pharma businesses to favour social sustainability. Surprisingly, the number of trainings followed by women leads companies to oppose, rather than favour, social sustainability. Pharma businesses also seem to be more in favour of social sustainability when they attribute an important role to the government as provider of social security. Companies having a higher net return on shareholder funds before taxes seem to be against social sustainability. Unlike a company's view on the environmental issue, its view on the social issue is not significantly influenced by its degree of foreign activity. In line with the environmental issue, the importance of stakeholders does not influence a company's view on social sustainability.

\section{Conclusions}

The aim of this paper was to explain Belgian pharmaceutical companies' views on sustainable development. The paper has shown that pharmaceutical companies' views on environmental and social sustainability are shaped by a similar group of factors, some differences notwithstanding. Their views on both issues are driven by internal as well as external factors. While internal factors relate to company-specific characteristics, the external factors include both the experienced international competition and the regulatory and legislative framework provided by the government.

Interesting is that pharmaceutical companies facing fierce competition (from other EU companies for the environmental issue and international competition for the social issue) favour corporate sustainability. This may indicate that perceived competition stimulates companies to gain competitive advantage through environmentfriendly and socially-oriented decisions leading to sustainable development.

Differing results arise for some of the internal characteristics. While patent activity and foreign activity respectively discourage and stimulate a company's environmental sustainability, they do not influence a company's view on the social issue, the latter being rather shaped by a company's percentage of R\&D. Hence, the expression as if globalisation would be present in all branches of society and driven by the same factors all over the world is (still) an overstatement, at least from the business perspective.

Also government regulation and legislative requirements are significant drivers of companies' awareness of sustainability issues. Hence, although the business world is mentioned along with the 'laissez-faire laissez-aller' principle, it needs governmental guidance on its way towards corporate sustainability.

The influence of a company's profitability and stakeholders on its decision-making needs further exploration. If government wants to guide businesses or if businesses want to guide themselves into the direction of sustainable development, then they need to know how these factors influence their corporate strategies.

\footnotetext{
${ }^{4}$ In the model we also distinguished between EU and non-EU competition. However, since no significant influence was reported, we did not include the results in the table.
} 
Table 1: Ordinary Least Squares Estimates For Environmental Issue

\begin{tabular}{|c|c|c|c|c|c|c|c|c|c|c|}
\hline & MODEL1 & MODEL2 & MODEL3 & MODEL4 & MODEL5 & MODEL6 & MODEL7 & MODEL8 & MODEL9 & MODEL10 \\
\hline $\begin{array}{c}\text { Percentage Research } \\
\text { and Development }\end{array}$ & & & & & & $\begin{array}{l}-0.19 \\
(0.36)\end{array}$ & $\begin{array}{l}-0.12 \\
(0.23)\end{array}$ & $\begin{array}{l}-0.18 \\
(0.34)\end{array}$ & $\begin{array}{l}-0.25 \\
(0.48) \\
\end{array}$ & $\begin{array}{l}-0.19 \\
(0.36)\end{array}$ \\
\hline Percentage of patents & $\begin{array}{l}-0.38 * * * \\
(1.89)\end{array}$ & $\begin{array}{l}-0.34 * * \\
(1.65) \\
\end{array}$ & $\begin{array}{l}-0.39 * * * \\
(1.92)\end{array}$ & $\begin{array}{l}-0.37 * * * \\
(1.87)\end{array}$ & $\begin{array}{l}-0.38 * * * \\
(1.90)\end{array}$ & & & & & \\
\hline $\begin{array}{c}\text { Competition from } \\
\text { outside the EU }\end{array}$ & $\begin{array}{l}-1.18 * * * \\
(2.11)\end{array}$ & $\begin{array}{l}-1.21 * * * \\
(2.24)\end{array}$ & $\begin{array}{l}-1.16 * * * \\
(2.04)\end{array}$ & $\begin{array}{l}-1.31 * * * * \\
(2.35)\end{array}$ & $\begin{array}{l}-1.22 * * * \\
(2.11)\end{array}$ & $\begin{array}{l}-1.06 * * \\
(1.81)\end{array}$ & $\begin{array}{l}-1.14 * * \\
(2.02)\end{array}$ & $\begin{array}{l}-1.11 * * \\
(1.84)\end{array}$ & $\begin{array}{l}-1.23 * * * \\
(2.11)\end{array}$ & $\begin{array}{l}-1.14 * * \\
(1.87)\end{array}$ \\
\hline $\begin{array}{c}\text { Competition from } \\
\text { inside the EU }\end{array}$ & $\begin{array}{l}1.55 * * * * \\
(2.36)\end{array}$ & $\begin{array}{l}1.56 * * * * \\
(2.42)\end{array}$ & $\begin{array}{l}1.54 * * * * \\
(2.37)\end{array}$ & $\begin{array}{l}1.72 * * * * \\
(2.55) \\
\end{array}$ & $\begin{array}{l}1.59 * * * \\
(2.29) \\
\end{array}$ & $\begin{array}{l}1.52 * * * \\
(2.19) \\
\end{array}$ & $\begin{array}{l}1.54 * * * \\
(2.29) \\
\end{array}$ & $\begin{array}{l}1.55 * * * \\
(2.25) \\
\end{array}$ & $\begin{array}{l}1.74 * * * * \\
(2.46)\end{array}$ & $\begin{array}{l}1.60 * * * \\
(2.18) \\
\end{array}$ \\
\hline Foreign activity & $\begin{array}{l}0.35 * * * \\
(1.86)\end{array}$ & $\begin{array}{l}0.36 * * * \\
(1.89)\end{array}$ & $\begin{array}{l}0.35 * * * \\
(1.86)\end{array}$ & $\begin{array}{l}0.35 * * * \\
(1.87)\end{array}$ & $\begin{array}{l}0.35 * * * \\
(1.85)\end{array}$ & $\begin{array}{l}0.26 * * \\
(1.34) \\
\end{array}$ & $\begin{array}{l}0.28 * * \\
(1.46) \\
\end{array}$ & $\begin{array}{l}0.26 * * \\
(1.34) \\
\end{array}$ & $\begin{array}{l}0.26 * * \\
(1.37) \\
\end{array}$ & $\begin{array}{l}0.26 * * \\
(1.32) \\
\end{array}$ \\
\hline $\begin{array}{c}\text { Net return on } \\
\text { shareholder funds } \\
\text { before taxes }\end{array}$ & $\begin{array}{l}-0.005 \\
(0.52)\end{array}$ & $\begin{array}{l}-0.005 \\
(0.48)\end{array}$ & $\begin{array}{l}-0.005 \\
(0.51)\end{array}$ & $\begin{array}{l}-0.004 \\
(0.44)\end{array}$ & $\begin{array}{l}-0.005 \\
(0.52)\end{array}$ & $\begin{array}{l}-0.0006 \\
(0.057)\end{array}$ & $\begin{array}{l}-0.0006 \\
(0.065)\end{array}$ & $\begin{array}{l}-0.0006 \\
(0.063)\end{array}$ & $\begin{array}{l}0.0004 \\
(0.04)\end{array}$ & $\begin{array}{l}-0.0005 \\
(0.05)\end{array}$ \\
\hline Iso 14000 norms & $\begin{array}{l}1.43 * * * * * \\
(2.96)\end{array}$ & $\begin{array}{l}1.46 * * * * * \\
(3.02)\end{array}$ & $\begin{array}{l}1.42 * * * * * \\
(2.93)\end{array}$ & $\begin{array}{l}1.43 * * * * * \\
(3.01)\end{array}$ & $\begin{array}{l}1.43 * * * * * \\
(2.97)\end{array}$ & $\begin{array}{l}1.57 * * * * * \\
(3.09)\end{array}$ & $\begin{array}{l}1.59 * * * * * \\
(3.20)\end{array}$ & $\begin{array}{l}1.56 * * * * * \\
(3.08)\end{array}$ & $\begin{array}{l}1.57 * * * * * \\
(3.15)\end{array}$ & $\begin{array}{l}1.57 * * * * * \\
(3.09)\end{array}$ \\
\hline $\begin{array}{c}\text { Government as } \\
\text { controller }\end{array}$ & $\begin{array}{l}0.52 \\
(0.82) \\
\end{array}$ & $\begin{array}{l}0.54 * \\
(0.86) \\
\end{array}$ & $\begin{array}{l}0.51 \\
(0.80) \\
\end{array}$ & $\begin{array}{l}0.49 \\
(0.78) \\
\end{array}$ & $\begin{array}{l}0.51 \\
(0.80) \\
\end{array}$ & $\begin{array}{l}0.42 \\
(0.63) \\
\end{array}$ & $\begin{array}{l}0.49 \\
(0.74) \\
\end{array}$ & $\begin{array}{l}0.42 \\
(0.63) \\
\end{array}$ & $\begin{array}{l}0.38 \\
(0.58)\end{array}$ & $\begin{array}{l}0.41 \\
(0.61)\end{array}$ \\
\hline $\begin{array}{c}\text { Government as } \\
\text { legislator }\end{array}$ & $\begin{array}{l}-0.27 \\
(0.40)\end{array}$ & $\begin{array}{l}-0.24 \\
(0.35)\end{array}$ & $\begin{array}{l}-0.28 \\
(0.41)\end{array}$ & $\begin{array}{l}-0.23 \\
(0.34)\end{array}$ & $\begin{array}{l}-0.27 \\
(0.39)\end{array}$ & $\begin{array}{l}-0.24 \\
(0.33)\end{array}$ & $\begin{array}{l}-0.18 \\
(0.25)\end{array}$ & $\begin{array}{l}-0.23 \\
(0.32)\end{array}$ & $\begin{array}{l}-0.19 \\
(0.27)\end{array}$ & $\begin{array}{l}-0.23 \\
(0.32)\end{array}$ \\
\hline Shareholders & $\begin{array}{l}0.06 \\
(0.11)\end{array}$ & & & & & $\begin{array}{l}0.15 \\
(0.24)\end{array}$ & & & & \\
\hline Employees & & $\begin{array}{l}-0.35 \\
(0.61) \\
\end{array}$ & & & & & $\begin{array}{l}0.69 * \circ \\
(1.01)\end{array}$ & & & \\
\hline Clients & & & $\begin{array}{l}-0.17 \\
(0.26)\end{array}$ & & & & & $\begin{array}{l}0.03 \\
(0.04)\end{array}$ & & \\
\hline Media & & & & $\begin{array}{l}0.52 \\
(0.76)\end{array}$ & & & & & $\begin{array}{l}0.64 * \\
(0.89)\end{array}$ & \\
\hline Green Ngos & & & & & $\begin{array}{l}-0.13 \\
(0.12) \\
\end{array}$ & & & & & $\begin{array}{l}-0.23 \\
(0.21) \\
\end{array}$ \\
\hline R-squared & 0.475 & 0.479 & 0.476 & 0.484 & 0.475 & 0.417 & 0.435 & 0.416 & 0.430 & 0.417 \\
\hline Adjusted R-squared & 0.323 & 0.328 & 0.324 & 0.335 & 0.323 & 0.248 & 0.271 & 0.246 & 0.265 & 0.247 \\
\hline F-Value & $3.12 * * * * *$ & $3.17 * * * * *$ & $3.13 * * * * *$ & $3.24 * * * * *$ & $3.12 * * * * *$ & $2.46 * * *$ & $2.64 * * * *$ & $2.45 * * *$ & $2.60 * * * *$ & $2.46 * * * *$ \\
\hline
\end{tabular}

Note: t-statistics in parentheses. One-tail tests, except for the variables on R\&D, competition and net return on shareholder funds before taxes.

$* * * *$ Significant at $1.0 \%$ level; **** Significant at $2.5 \%$ level; *** Significant at $5 \%$ level; ** Significant at $10 \%$ level; * Significant at $20 \%$ level

${ }^{\circ}$ Significant but unexpected sign 
Table 2: Ordinary Least Squares Estimates For Social Issue

\begin{tabular}{|c|c|c|c|c|c|c|c|c|}
\hline & MODEL1 & MODEL2 & MODEL3 & MODEL4 & MODEL5 & MODEL6 & MODEL7 & MODEL8 \\
\hline $\begin{array}{c}\text { Percentage Research and } \\
\text { Development }\end{array}$ & $\begin{array}{l}1.91 * * * * * \\
(2.87)\end{array}$ & $\begin{array}{l}1.85 * * * * * \\
(2.79)\end{array}$ & $\begin{array}{l}1.81 * * * * * \\
(2.76)\end{array}$ & $\begin{array}{l}1.77 * * * * \\
(2.61)\end{array}$ & & & & \\
\hline Percentage of patents & & & & & $\begin{array}{l}-0.28 \\
(0.85)\end{array}$ & $\begin{array}{l}-0.41 * \\
(1.20)\end{array}$ & $\begin{array}{l}-0.36 * \\
(1.13)\end{array}$ & $\begin{array}{l}-0.26 \\
(0.84)\end{array}$ \\
\hline Total foreign competition & $\begin{array}{l}1.75 * * \\
(1.81)\end{array}$ & $\begin{array}{l}1.83 * * \\
(1.91)\end{array}$ & $\begin{array}{l}1.67 * * \\
(1.76)\end{array}$ & $\begin{array}{l}1.87 * * \\
(1.95)\end{array}$ & $\begin{array}{l}1.37 \\
(1.19)\end{array}$ & $\begin{array}{l}1.23 \\
(1.08)\end{array}$ & $\begin{array}{l}1.05 \\
(0.93)\end{array}$ & $\begin{array}{l}1.49 \\
(1.32)\end{array}$ \\
\hline Foreign activity & $\begin{array}{l}-0.11 \\
(0.34)\end{array}$ & $\begin{array}{l}-0.05 \\
(0.16)\end{array}$ & $\begin{array}{l}-0.14 \\
(0.45)\end{array}$ & $\begin{array}{l}-0.01 \\
(0.04)\end{array}$ & $\begin{array}{l}0.37 * \\
(0.92)\end{array}$ & $\begin{array}{l}0.45 * \\
(1.18)\end{array}$ & $\begin{array}{l}0.27 \\
(0.73)\end{array}$ & $\begin{array}{l}0.41 * \\
(1.11)\end{array}$ \\
\hline $\begin{array}{c}\text { Net return on } \\
\text { shareholder funds before } \\
\text { taxes }\end{array}$ & $\begin{array}{l}-0.02 * \\
(1.46)\end{array}$ & $\begin{array}{l}-0.02 * \\
(1.49)\end{array}$ & $\begin{array}{l}-0.02 * \\
(1.50)\end{array}$ & $\begin{array}{l}-0.02 * \\
(1.39)\end{array}$ & $\begin{array}{l}-0.02 * \\
(1.58)\end{array}$ & $\begin{array}{l}-0.03 * * \\
(1.79)\end{array}$ & $\begin{array}{l}-0.03 * * \\
(1.73)\end{array}$ & $\begin{array}{l}-0.02 * \\
(1.47)\end{array}$ \\
\hline Government as legislator & $\begin{array}{l}-0.94 * \circ \\
(1.23)\end{array}$ & $\begin{array}{l}-0.85 * \circ \\
(1.17)\end{array}$ & $\begin{array}{l}-1.21 * * \circ \\
(1.51)\end{array}$ & $\begin{array}{l}-0.69 * \circ \\
(0.94)\end{array}$ & $\begin{array}{l}-0.48 \\
(0.55)\end{array}$ & $\begin{array}{l}-0.59 \\
(0.72)\end{array}$ & $\begin{array}{l}-1.07 * \circ \\
(1.19)\end{array}$ & $\begin{array}{l}-0.31 \\
(0.38)\end{array}$ \\
\hline $\begin{array}{c}\text { Government as provider } \\
\text { of social security }\end{array}$ & $\begin{array}{l}1.41 * * * \\
(1.99)\end{array}$ & $\begin{array}{l}1.38 * * * \\
(1.87)\end{array}$ & $\begin{array}{l}1.22 * * \\
(1.67)\end{array}$ & $\begin{array}{l}1.46 * * * * \\
(2.06)\end{array}$ & $\begin{array}{l}1.90 * * * * \\
(2.39)\end{array}$ & $\begin{array}{l}1.69 * * * * \\
(2.09)\end{array}$ & $\begin{array}{l}1.55 * * * \\
(1.93)\end{array}$ & $\begin{array}{l}1.85 \\
(2.39)\end{array}$ \\
\hline Training men & $\begin{array}{l}0.041 * * * * \\
(2.29)\end{array}$ & $\begin{array}{l}0.039 * * * * \\
(2.22)\end{array}$ & $\begin{array}{l}0.042 * * * * \\
(2.38)\end{array}$ & $\begin{array}{l}0.038 * * * * \\
(2.16)\end{array}$ & $\begin{array}{l}0.027 * * \\
(1.34)\end{array}$ & $\begin{array}{l}0.026 * \\
(1.31) \\
\end{array}$ & $\begin{array}{l}0.029 * * \\
(1.56)\end{array}$ & $\begin{array}{l}0.026 * * \\
(1.34) \\
\end{array}$ \\
\hline Training women & $\begin{array}{l}-0.060 * * * * \circ \\
(2.19)\end{array}$ & $\begin{array}{l}-0.058 * * * * * \circ \\
(2.24)\end{array}$ & $\begin{array}{l}-0.061 * * * * \circ \\
(2.36)\end{array}$ & $\begin{array}{l}-0.057 * * * * \circ \\
(2.19)\end{array}$ & $\begin{array}{l}-0.042 * * \circ \\
(1.41)\end{array}$ & $\begin{array}{l}-0.040 * * \circ \\
(1.38)\end{array}$ & $\begin{array}{l}-0.045 * * \circ \\
(1.57)\end{array}$ & $\begin{array}{l}-0.040 * * \circ \\
(1.41)\end{array}$ \\
\hline Percentage homeworkers & $\begin{array}{l}-0.49 * \circ \\
(1.05) \\
\end{array}$ & $\begin{array}{l}-0.44 * 0 \\
(0.95)\end{array}$ & $\begin{array}{l}-0.40 * 0 \\
(0.86)\end{array}$ & $\begin{array}{l}-0.46 * 0 \\
(1.01)\end{array}$ & $\begin{array}{l}-0.44 \\
(0.85) \\
\end{array}$ & $\begin{array}{l}-0.37 \\
(0.71) \\
\end{array}$ & $\begin{array}{l}-0.34 \\
(0.67)\end{array}$ & $\begin{array}{l}-0.43 \\
(0.84)\end{array}$ \\
\hline Shareholders & $\begin{array}{l}0.44 \\
(0.55) \\
\end{array}$ & & & & $\begin{array}{l}0.03 \\
(0.03) \\
\end{array}$ & & & \\
\hline Employees & & $\begin{array}{l}0.36 \\
(0.41)\end{array}$ & & & & $\begin{array}{l}1.03 \\
(0.96)\end{array}$ & & \\
\hline Clients & & & $\begin{array}{l}-0.98 * * \circ \\
(1.06)\end{array}$ & & & & $\begin{array}{l}-1.43 * \circ \\
(1.37)\end{array}$ & \\
\hline Media & & & & $\begin{array}{l}0.72 \\
(0.58) \\
\end{array}$ & & & & $\begin{array}{l}1.44 * \\
(1.07)\end{array}$ \\
\hline R-squared & 0.524 & 0.522 & 0.539 & 0.525 & 0.385 & 0.407 & 0.427 & 0.412 \\
\hline Adjusted R-squared & 0.334 & 0.330 & 0.355 & 0.335 & 0.138 & 0.169 & 0.199 & 0.176 \\
\hline F-Value & $2.75 * * * *$ & $2.72 * * * *$ & $2.93 * * * *$ & $2.76 * * * *$ & $1.56 *$ & $1.71 *$ & $1.87 *$ & $1.75 *$ \\
\hline
\end{tabular}

Note: t-statistics in parentheses. One-tail tests, except for the variables on R\&D, competition and net return on shareholder funds before taxes.

***** Significant at $1.0 \%$ level; **** Significant at $2.5 \%$ level; *** Significant at 5\% level; ** Significant at $10 \%$ level; * Significant at $20 \%$ level

${ }^{\circ}$ Significant but unexpected sign 


\section{References}

1. Alexander, G.J. \& Bucholz, R.A. (1978). "Corporate Social Responsibility and Stock Market Performance", Academy of Management Journal, Vol. 21(3), pp. 479-486.

2. Anderson, J.C. \& Frankle, A.W. (1980). "Voluntary Social Reporting: An Iso-Beta Portfolio Analysis", The Accounting Review, Vol. 55, pp. 467-479.

3. Aupperle, K.E.; Carroll, A.B. \& Hatfield, J.D. (1985). "An Empirical Examination of the Relationship Between Corporate Social Responsibility and Profitability”, Academy of Management Journal, Vol. 28 (2), pp. 446-463.

4. Belkaoui, A. (1976). "The Impact of the Disclosure of the Environmental Effects of Organizational Behavior on the Market", Financial Management, Vol. 5 (4),pp. 26-31.

5. Blum - Kusterer, M. \& Hussain, S.S. (2001). "Innovation and corporate sustainability: an investigation into the process of change in the pharmaceuticals industry", Business Strategy and the Environment, Vol. 10, pp. 300-316.

6. Bowman, E.H. (1978). "Strategy, Annual Reports, and Alchemy", California Management Review, Vol. 20 (3),pp. 64-71.

7. Bowman, E.H. \& Haire, M. (1975). "A Strategic Posture Toward Corporate Social Responsibility", California Management Review, Vol. 18(2), pp. 49-58.

8. $\quad$ Bragdon, J. H. \& Marlin, J.T. (1972). "Is Pollution Profitable?", Risk Management, Vol. 19(2), pp. 9-18.

9. Bromiley, P. \& Marcus, A. (1989). "The Deterrent to Dubious Corporate Behavior: Profitability, Probability, and Safety Recalls", Strategic Management Journal, Vol. 10, pp. 233-250.

10. Chen, K. \& Metcalf, R. (1984). "The Relationship Between Pollution Control Record and Financial Indicators Revisited", The Accounting Review, Vol. 55, pp. 168-177.

11. Chugh, L.; Haneman, M. \& Mahapatra, S. (1978). "Impact of Pollution Control Regulations on the Market Risk of Securities in the U.S.”, Journal of Economic Studies, Vol. 5, pp. 64-70.

12. Cochran, P. \& Wood, R. (1984). "Corporate Social Responsibility and Financial Performance", Academy of Management Journal, Vol. 27, pp. 42-56.

13. Cotrill, M.T. (1990). "Corporate Social Responsibility and the Marketplace", Journal of Business Ethics, pp. 723-729.

14. Cowen, S.S.; Ferreri, L.B. \& Parker, D.B. (1987). "The Impact of Corporate Characteristics on Social Responsibility Disclosure: A Typology and Frequency-Based Analysis”, Accounting Organizations and Society, Vol. 12 (2),pp. 111-122.

15. Davidson, W.N.; Chandy, P.R. \& Cross, M. (1987). "Large Losses, Risk Management and Stock Returns in the Airline Industry", Journal of Risk and Insurance, Vol. 55, pp. 162-172.

16. Davidson, W.N. \& Worrell, D.L. (1988). "The Impact of Announcements of Corporate Illegalities on Shareholder Returns", Academy of Management Journal, Vol. 31 (1), pp. 195-200.

17. Dyllick, T. \& Hockerts, K. (2002). "Beyond the business case for corporate sustainability", Business Strategy and the Environment, Vol. 11, pp. 130-141.

18. Eckbo, B.E. (1983). "Horizontal Mergers, Collusion, and Stockholder Wealth", Journal of Financial Economics, Vol. 11, pp. 241-273.

19. Fogler, H.R. \& Nutt, E. (1975). "A Note on Social Responsibility and Stock Valuation", Academy of Management Journal, Vol. 18(1), pp. 155-166.

20. Freedman, M. \& Jaggi, B. (1982). "Pollution Disclosures, Pollution Performance and Economic Performance", Omega, Vol. 10(2), pp. 167-176.

21. Freedman, M. \& Jaggi, B. (1986). "An Analysis of the Impact of Corporate Pollution Disclosures Included in Annual Financial Statements on Investors' Decisions", In: Neimark, M. (ed.), Advances in Public Interest Accounting. Greenwich, CT: JAI. Friedman, pp.193-212.

22. Fry, E.L; Keim,G.D \& Meiners, R.E. (1982). “Corporate Contributions: Altruistic or for Profit?” Academy of Management Journal, Vol. 25(1), pp. 94-106.

23. Frooman, J. (1997). "Socially irresponsible and illegal behaviour and shareholder wealth", Business and Society, Vol 36 (3),pp. 221-249.

24. Graves, S.B. \& Waddock, S.A. (1994). "Institutional Owners and Corporate Social Performance", Academy of Management Journal, Vol. 37(4), pp. 1034-1046. 
25. Hart, S.L. \& Ahuja, G. (1994). "Does it pay to be green? An empirical examination of the relationship between pollution prevention and firm performance". Academy of Management conference paper.

26. Heinze, D. (1976). "Financial Correlates of a Social Involvement Measure", Akron Business and Economic Review, Vol. 7 (1), pp. 48-51.

27. Henriques, I. \& Sadorsky, P. (1996), "The Determinants of an Environmentally Responsive Firm: An Empirical Approach", Journal Of Environmental Economics And Management, Vol. 30, pp. 381-395.

28. Hoffer, G.E.; Pruitt, S.W. \& Reilly, R.J. (1988). "The Impact of Product Recalls on the Wealth of Sellers: A Reexamination", Journal of Political Economy, Vol. 96(3), pp. 663-670.

29. Ingram, R.W. (1978). "An Investigation of the Information Content of (Certain) Social Responsibility Disclosures", Journal of Accounting Research, Vol. 16(2), pp. 270-285.

30. Jarrell, G. \& Peltzman, S. (1985). "The Impact of Product Recalls on the Wealth of Sellers", Journal of Political Economy, Vol. 93(3), pp. 512-536.

31. Marcus, A.A. \& Goodman, R.S. (1986). "Compliance and Performance: Toward a Contingency Theory", IN Preston, L.E. \& Post, J.E. (ed.), Research in Corporate Social Performance and Policy, Vol. 8. Greenwich, CT: JAI., pp. 193-221

32. McGuire, J.B.; Sundgren, A. \& Schneeweis, T. (1988). "Corporate Social Responsibility and Firm Financial Performance”, Academy of Management Journal, Vol. 31(4), pp. 854-872.

33. Mc Williams, A \& Siegel, D. (2000). "Corporate social responsibility and financial performance: correlation or misspecification?" Strategic Management Journal, Vol. 21, pp. 603-609.

34. Meznar, B.M. \& Johnson J.H. (jr.) (1996). "Multinational Operations And Stakeholders Management: Internationalisation, Public Affairs Strategies and Economic Performance", Journal Of International Management, Vol. 2(4), pp.233-261.

35. Morris, S.A.; Rehbein, K.A.; Hosseini, J.C. \& Armacost, R.L. (1990). "Building a Profile of Socially Responsive Firms", IN: Wood, D.J. \& Martello, W.E. (eds.), Proceedings of the International Association for Business and Society, pp. 297-303.

36. Moskowitz, M. (1975). "Choosing Socially Responsible Stocks", Business and Society Review, Vol. 10, pp. 71-75.

37. Olitzky, M. \& Benjamin, J.D. (2001). "Corporate social performance and firm risk: A meta-analytic review”, Business \& Society, Vol. 40 (4),pp. 369-396.

38. Olitzky, M. (2001). "Does organizational size confound the relationship between Corporate social performance and firm financial performance?” Journal Of Business Ethics, Vol. 33(2), pp. 167-180.

39. Patten, D. M. (1990). "The Market Reaction to Social Responsibility Disclosures: the Case of the Sullivan Principles Signings", Accounting, Organizations and Society, Vol. 15, pp. 575-587.

40. Patton, D. (2003). "Corporate responsibility and the environment", In: Worthinghon, I. and Brittan, C. The Business Environment, Prentice Hall.

41. Parket, R. \& Eilbert, H. (1975). "Social Responsibility: The Underlying Factors", Business Horizons, Vol 18(4), pp. 5-11.

42. Poduska, R.; Forbes, R. \& Bober, M. (1992). "The challenge of sustainable development: Kodak's Response" Columbia Journal of World Business, Vol.27, pp. 286-291.

43. Porter, M.E. (1991), “America's green strategy,” Scientific American, p. 168.

44. Porter M. \& Van Der Linde C. (1995). "Towards a New Conception of the Environment-Competitiveness relationship", Journal of Economic Perspectives, Vol. 6(4), pp. 119-132.

45. Preston, L.E. \& O’Bannon, D.P. (1997). “The corporate social-financial performance relationship", Business and Society, Vol. 36 (4), pp. 419-429.

46. Reilly, W. (1992), “Environment, Inc”, Business Horizons, Vol.35(2), pp. 9-11.

47. Roberts, R.W. (1992). "Determinants of corporate social responsibility disclosure: an application of stakeholder theory", Accounting, Organizations and Society, Vol. 17(6), pp. 595-612.

48. Rockness, J.; Schlachter,P. \& Rockness, H.O. (1986). "Hazardous Waste Disposal, Corporate Disclosure, and Financial Performance in the Chemical Industry", Advances in Public Interest Accounting, Vol. 1, pp. 167-191.

49. Roman, R.M.; Hayibor, S. \& Agle, B.R. (1999). "The relationship between social and financial performance", Business and society, Vol. 38 (1), pp.109-125. 
50. Shane, P.B. \& Spicer, B.H. (1983). "Market Response to Environmental Information Produced Outside the Firm", The Accounting Review, Vol. 58(3), pp. 521-538.

51. Simpson, W.G. \& Kohers, T. (2002). "The link between corporate social and financial performance: Evidence from the banking industry", Journal of Business Ethics, Vol. 35, pp. 97-109.

52. Spicer, B.H. (1978). "Investors, Corporate Social Performance and Information Disclosure: An Empirical Study", The Accounting Review, Vol. 53 (1), pp. 94-111.

53. Spencer, B.A. \& Taylor, G. S. (1987). "A within and between analysis of the relationship between corporate social responsibility and financial performance", Akron Business And Economic Review, Vol. 18(3), pp. 7-18.

54. Strachan, J.L.; Smith, D.B. \& Beedles, W.L. (1983). "The Price Reaction to Corporate Crime", The Financial Review, Vol. 18(2), pp. 121-132.

55. Sturdivant, F.D. \& Ginter, J.L. (1977). "Corporate Social Responsiveness: Management Attitudes and Economic Performance”, California Management Review, Vol. 19(3), pp. 30-39.

56. Vance, S.C. (1975). “Are Socially Responsible Corporations Good Investment Risks?” Academy of Management Review, (August), pp. 18-24.

57. Wier, P. (1983). "The Costs of Antimerger Lawsuits: Evidence From the Stock Market", Journal of Financial Economics, Vol. 11, pp. 207-224.

58. Wokutch, R.E. \& Spencer, B.A. (1987). "Corporate Saints and Sinners. The Effects of Philanthropic and Illegal Activity on Organizational Performance”, California Management Review, Vol. 29(2), pp. 62-77. 